Article

\title{
Separation and Identification of Four New Compounds with Antibacterial Activity from Portulaca oleracea $\mathrm{L}$.
}

\author{
Xia Lei, Jianmin Li, Bin Liu, Ning Zhang and Haiyang Liu * \\ Basic research department of Jiamusi College, Heilongjiang University of Chinese Medicine, \\ No. 39 Guang Hua Street, Qian Jin District, Jia Mu Si 154100, China; \\ E-Mails: leixia2006@163.com (X.L.);jmsxyrsk@163.com (J.L.); \\ liubin169@163.com (B.L.); zhangning345678@163.com (N.Z.) \\ * Author to whom correspondence should be addressed; E-Mail: haiyangliu2015@163.com; \\ Tel./Fax: +86-045-461-039-92.
}

Academic Editor: Peter J. Rutledge

Received: 21 July 2015 / Accepted: 28 August 2015 / Published: 10 September 2015

\begin{abstract}
The Portulaca oleracea L. (P. oleracea) has been used to treat bacillary dysentery for thousands of years in China. Pharmacology studies on $P$. oleracea have also showed its significant antibacterial effects on the enteropathogenic bacteria, which might reveal the treatment of $P$. oleracea in cases of bacillary dysentery to some extent. To date, however, the therapeutic basis of $P$. oleracea treating on bacillary dysentery remains unknown. We determined the antibacterial effective fraction of $P$. oleracea in a previous study. The current study, which is based on our previous study, was first designed to isolate, identify and screen antibacterial active constituents from $P$. oleracea. As a result, four new compounds (1-4), portulacerebroside B (1), portulacerebroside C (2), portulacerebroside D (3) and portulaceramide A (4) along with five known compounds (5-9) were isolated, and structures were established by their physico-chemical constants and spectroscopic analysis. The antibacterial activities against common enteropathogenic bacteria were evaluated for all compounds and the new compounds 1-4 showed significant antibacterial effect on enteropathogenic bacteria in vitro, which might contribute to revealing the treatment of $P$. oleracea in cases of bacillary dysentery.
\end{abstract}

Keywords: Portulaca oleracea L.; antibacterial activity; ceramides; cerebrosides; enteropathogenic bacteria 


\section{Introduction}

The genus of Portulaca is an annual herb which taxonomically belongs to the family of Portulacaceae. Although it originates from India, Portulaca has been widely distributed in other temperate and tropical areas of the world [1,2]. In China, there are six species of Portulaca, among which Portulaca oleracea L. (P. oleracea) has been used as a traditional Chinese medicine (TCM) for thousands of years. P. oleracea, cold in nature and acid in flavor, possesses the efficacies of clearing away the heat evil and detoxifying and cooling blood to stop diarrhea. In clinical situations, P. oleracea has been used to treat acute appendicitis, scrofula ulcer, pediatric pertussis, burns and scalds, psoriasis [3], hemorrhinia, uterine bleeding, urinary tract infections, lung abscess, mumps, and especially more effective in bacillary dysentery which manifested feeling cold or fever, bellyache, diarrhea, tenesmus, and mucus pus blood stool [2]. Chemical studies on P. oleracea showed its main constituents of fatty acids, terpenes, alkaloids, coumarins, flavonoids, and volatile oil [2]. In addition, the only cerebroside of portulacerebroside A was reported in 2008 [4]. Pharmacology studies on P. oleracea showed its activities of antibacterial $[5,6]$, hepatoprotective [7,8], anti-inflammatory, analgesia [2,9], muscle relaxant [10], neuroprotective [11], anti-oxidant [1], and anti-aging [12], but studies on the corresponding therapeutic basis were far from sufficient. Obviously, the treatment of $P$. oleracea on bacillary dysentery results from its antibacterial effect on the enteropathogenic bacteria; however, the corresponding active components in $P$. oleracea were unknown. Consequently, we screened and obtained the antibacterial fraction (EtOAc extract) from $P$. oleracea. The effective fraction could inhibit and kill the common enteropathogenic bacteria in vitro effectively, based on which a bioassay-guided isolation and phytochemical study of $P$. oleracea was performed and four new along with five known compounds were obtained from the effective fraction. The structures of known compounds 5-9 were determined by detailed 1D- and 2D-NMR analyses, ESI-MS and comparison of their spectral data with literature values was undertaken. In this paper, the isolation and structural elucidation of the new compounds 1-4 was described. We also investigated the antibacterial effects of compounds 1-9 against common enteropathogenic bacteria in vitro.

\section{Results and Discussion}

Compound 1 was obtained as white amorphous powder, $[\alpha]_{\mathrm{D}}^{22}=+13.3^{\circ}\left(c=0.52, \mathrm{C}_{5} \mathrm{H}_{5} \mathrm{~N}\right)$. The molecular formula $\mathrm{C}_{39} \mathrm{H}_{75} \mathrm{NO}$, was established for 1 by HRESIMS $m / z 702.5516[\mathrm{M}+\mathrm{H}]^{+}$(calc. for 702.5520), indicating three degrees of unsaturation. Methanolysis experiment of 1 liberated D-glucose suggested that 1 was a D-glucoside. The IR absorption bands at $3420 \mathrm{~cm}^{-1}, 1645$ and $1542 \mathrm{~cm}^{-1}$, and $722 \mathrm{~cm}^{-1}$ originated from hydroxyl, amide, and methylene groups, respectively.

The ${ }^{1} \mathrm{H}$ - and ${ }^{13} \mathrm{C}-\mathrm{NMR}$ data (anomeric proton $\delta_{\mathrm{H}} 4.90,1 \mathrm{H}, \mathrm{d}, J=7.6 \mathrm{~Hz}$; $\delta_{\mathrm{C}} 105.7,75.2,78.5,71.6$, 78.6, and 62.7 ) of 1 suggested the presence of a $\beta$-D-glucopyranosyl moiety. The ${ }^{1} \mathrm{H}$ - and ${ }^{13} \mathrm{C}-\mathrm{NMR}$ spectra (Tables 1 and 2) showed characteristics of a cerebroside with a 2-hydroxy fatty acid fraction as the aglycone of $\mathbf{1}$. Methanolysis of $\mathbf{1}$ obtained a fatty acid methyl ester (FAME) and a long-chain base (LCB). The FAM was determined as 2-hydroxypentadecanoic acid methyl ester by Gas Chromatography-Mass Spectrometer (GC-MS) analysis. The 1D-TOCSY spectrum of 1 showed a correlation between $\delta_{\mathrm{H}} 4.22(1 \mathrm{H}, \mathrm{m}, \mathrm{H}-3)$ and $5.46(2 \mathrm{H}, \mathrm{m}, \mathrm{H}-8,9)$, which suggested the olefinic bond was located in the LCB. To determine the location of the olefinic bond in LCB, the dimethyl disulfide 
(DMDS) derivatives of the LCB was analyzed by ESIMS and characteristic fragment ion of $\mathrm{m} / \mathrm{z} 187$ $[\mathrm{M}+\mathrm{H}]^{+}$was obtained. Therefore, the olefinic bond was located at C-8 and C-9. The LCB was further determined as 2-aminooctadec-8-ene-1,3-diol by GC-MS analysis (Figure 1). The specific rotation $[\alpha]_{\mathrm{D}}^{22}=-5.8^{\circ}\left(c=0.02, \mathrm{CHCl}_{3}\right)$ of the FAM confirmed that the absolute configuration of $\mathrm{C}-2^{\prime} R$ [13]. The $2 S, 3 R$ stereochemistry was determined by comparing of the ${ }^{13} \mathrm{C}-\mathrm{NMR}$ data of C-2 and C-3 with those in references [14-16]. The trans-configuration $(E)$ of the olefinic bond in 1 was determined by signals at $\delta_{\mathrm{C}} 33.2 / 32.1$ of the two carbons next to the olefinic bond in ${ }^{13} \mathrm{C}-\mathrm{NMR}$ spectrum [9]. The ${ }^{1} \mathrm{H}-$ and ${ }^{13} \mathrm{C}-\mathrm{NMR}$ data (Tables 1 and 2) were further assigned by the spectra of DEPT, HSQC, ${ }^{1} \mathrm{H}-{ }^{1} \mathrm{H}$ COSY, and HMBC. Consequently, 1 was established as 1-O- $\beta$-D-glucopyranosyl- $(2 S, 3 R, 8 E)-2-\left[\left(2^{\prime} R\right)-2-\right.$ hydroxylpentadecanoylamino]-8-octadecene-1,3-diol which is named as portulacerebroside B (Figure 2).

Table 1. ${ }^{1} \mathrm{H}-\mathrm{NMR}$ data of compounds $1-4\left(400 \mathrm{MHz}, \delta\right.$ in ppm, $J$ in $\mathrm{Hz}$, in $\mathrm{C}_{5} \mathrm{D}_{5} \mathrm{~N}-d_{5}$ at $\left.30{ }^{\circ} \mathrm{C}\right)$.

\begin{tabular}{|c|c|c|c|c|c|c|c|}
\hline & 1 & & 2 & & 3 & & 4 \\
\hline $\mathrm{H}$ & $\delta_{\mathrm{H}}(J, \mathrm{~Hz})$ & $\mathrm{H}$ & $\delta_{\mathrm{H}}(J, \mathrm{~Hz})$ & $\mathrm{H}$ & $\delta_{\mathrm{H}}(J, \mathrm{~Hz})$ & $\mathrm{H}$ & $\delta_{\mathrm{H}}(J, \mathrm{~Hz})$ \\
\hline $\mathrm{NH}$ & $8.40, \mathrm{~d}(8.4)$ & $\mathrm{NH}$ & $8.36, \mathrm{~d}(8.0)$ & $\mathrm{NH}$ & $8.36, \mathrm{~d}(8.0)$ & $\mathrm{NH}$ & $8.55, \mathrm{~d}(8.0)$ \\
\hline \multirow{2}{*}{1} & 4.35 , dd $(11.6,5.6)$ & \multirow{2}{*}{1} & $4.22, \mathrm{~m}$ & \multirow{2}{*}{1} & $4.22, \mathrm{~m}$ & \multirow{2}{*}{1} & $4.49, \mathrm{dd}(11.0,4.6)$ \\
\hline & $4.73, \mathrm{~m}$ & & $4.72, \mathrm{~m}$ & & $4.72, \mathrm{~m}$ & & $4.41, \mathrm{dd}(11.0,4.8)$ \\
\hline 2 & $4.60, \mathrm{~m}$ & 2 & $4.78, \mathrm{~m}$ & 2 & $4.78, \mathrm{~m}$ & 2 & $5.10, \mathrm{~m}$ \\
\hline 3 & $4.22, \mathrm{~m}$ & 3 & $4.76, \mathrm{~m}$ & 3 & $4.76, \mathrm{~m}$ & 3 & $4.34, \mathrm{dd}(4.8,6.4)$ \\
\hline $4-6$ & $1.15-1.40$, brs & 4 & $5.86, \mathrm{~m}$ & 4 & $5.86, \mathrm{~m}$ & 4 & $4.27, \mathrm{~m}$ \\
\hline 7 & $2.10, \mathrm{~m}$ & 5 & $5.98, \mathrm{~m}$ & 5 & $5.98, \mathrm{~m}$ & 5 & $2.22,1.96, \mathrm{~m}$ \\
\hline 8 & $5.46, \mathrm{~m}$ & 6 & $2.05, \mathrm{~m}$ & 6 & $2.05, \mathrm{~m}$ & 6 & $1.67, \mathrm{~m}$ \\
\hline 9 & $5.46, \mathrm{~m}$ & $7-16$ & $1.16-1.42$, brs & $7-17$ & $1.16-1.42$, brs & 7 & $2.01, \mathrm{~m}$ \\
\hline 10 & $2.02, \mathrm{~m}$ & 17 & $0.88, \mathrm{t}(6.4)$ & 18 & $0.88, \mathrm{~d}(7.4)$ & 8 & $5.52, \mathrm{~m}$ \\
\hline $11-17$ & $1.15-1.40$, brs & $2^{\prime}$ & $4.60, \mathrm{~m}$ & 19 & $0.86, \mathrm{t}(6.4)$ & 9 & $5.52, \mathrm{~m}$ \\
\hline 18 & $0.85, \mathrm{t}(6.4)$ & $3^{\prime}$ & $1.86, \mathrm{~m}$ & $2^{\prime}$ & $4.60, \mathrm{~m}$ & 10 & $1.89, \mathrm{~m}$ \\
\hline $2^{\prime}$ & $4.70, \mathrm{~m}$ & $4^{\prime}$ & $\begin{array}{c}1.73, \mathrm{~m} \\
1.16-1.42, \mathrm{brs}\end{array}$ & $3^{\prime}$ & $1.86, \mathrm{~m}$ & 11 & $1.26-1.38$, brs \\
\hline $3^{\prime}$ & $1.86, \mathrm{~m}$ & $5^{\prime}-14^{\prime}$ & $1.16-1.42$, brs & $4^{\prime}$ & $\begin{array}{c}1.73, \mathrm{~m} \\
1.16-1.42, \text { brs }\end{array}$ & 12 & $0.88, \mathrm{t}(6.8)$ \\
\hline $4^{\prime}$ & $\begin{array}{c}1.73, \mathrm{~m} \\
1.15-1.40, \text { brs }\end{array}$ & $15^{\prime}$ & $0.88, \mathrm{t}, 6.4$ & $5^{\prime}-21^{\prime}$ & $1.16-1.42$, brs & $2^{\prime}$ & 4.60, dd $(7.6,3.2)$ \\
\hline $5^{\prime}-14^{\prime}$ & $1.15-1.40$, brs & $1^{\prime \prime}$ & $4.90, d,(7.6)$ & $22^{\prime}$ & $0.88, \mathrm{t}(6.4)$ & $3^{\prime}$ & $2.18,2.02, \mathrm{~m}$ \\
\hline $15^{\prime}$ & $0.85, \mathrm{t}(6.4)$ & $2^{\prime \prime}$ & $4.01, \mathrm{~m}$ & $1^{\prime \prime}$ & $4.90, \mathrm{~d},(7.6)$ & $4^{\prime}$ & $1.96,1.73, \mathrm{~m}$ \\
\hline $1^{\prime \prime}$ & $4.90, \mathrm{~d}(7.6)$ & $3^{\prime \prime}$ & $4.22, \mathrm{~m}$ & $2^{\prime \prime}$ & $4.01, \mathrm{~m}$ & $5^{\prime}-14^{\prime}$ & $1.26-1.38$, brs \\
\hline $2^{\prime \prime}$ & 3.91, m & $4^{\prime \prime}$ & $4.22, \mathrm{~m}$ & $3^{\prime \prime}$ & $4.22, \mathrm{~m}$ & $15^{\prime}$ & $0.88, \mathrm{t}(6.8)$ \\
\hline $3^{\prime \prime}$ & $4.20, \mathrm{~m}$ & $5^{\prime \prime}$ & $3.89, \mathrm{~m}$ & $4^{\prime \prime}$ & $4.22, \mathrm{~m}$ & & \\
\hline $4^{\prime \prime}$ & $4.03, \mathrm{~m}$ & $6^{\prime \prime}$ & $4.34,4.49, \mathrm{~m}$ & $5^{\prime \prime}$ & $3.89, \mathrm{~m}$ & & \\
\hline $5^{\prime \prime}$ & $4.12, \mathrm{~m}$ & & & $6^{\prime \prime}$ & $4.34,4.49, \mathrm{~m}$ & & \\
\hline $6^{\prime \prime}$ & $4.18,4.52, \mathrm{~m}$ & & & & & & \\
\hline
\end{tabular}


Table 2. ${ }^{13} \mathrm{C}-\mathrm{NMR}$ data of compounds $\mathbf{1}-\mathbf{4}\left(100 \mathrm{MHz}, \delta\right.$ in ppm, in $\mathrm{C}_{5} \mathrm{D}_{5} \mathrm{~N}-d_{5}$ at $\left.30{ }^{\circ} \mathrm{C}\right)$.

\begin{tabular}{|c|c|c|c|c|c|c|c|}
\hline \multicolumn{2}{|r|}{1} & \multicolumn{2}{|r|}{2} & \multicolumn{2}{|r|}{3} & \multicolumn{2}{|r|}{4} \\
\hline $\mathrm{C}$ & $\delta_{\mathrm{C}}$ & $\mathrm{C}$ & $\delta_{\mathrm{C}}$ & $\mathrm{C}$ & $\delta_{\mathrm{C}}$ & $\mathrm{C}$ & $\delta_{\mathrm{C}}$ \\
\hline 1 & $70.4, \mathrm{CH}_{2}$ & 1 & $70.2, \mathrm{CH}_{2}$ & 1 & $70.4, \mathrm{CH}_{2}$ & 1 & $62.0, \mathrm{CH}_{2}$ \\
\hline 2 & $54.6, \mathrm{CH}$ & 2 & $54.6, \mathrm{CH}$ & 2 & $54.5, \mathrm{CH}$ & 2 & $52.9, \mathrm{CH}$ \\
\hline 3 & $71.3, \mathrm{CH}$ & 3 & $72.4, \mathrm{CH}$ & 3 & $72.4, \mathrm{CH}$ & 3 & $76.8, \mathrm{CH}$ \\
\hline $4-6$ & $29.5-30.4, \mathrm{CH}_{2}$ & 4 & 131.6, CH & 4 & $131.7, \mathrm{CH}$ & 4 & $72.4, \mathrm{CH}$ \\
\hline 7 & 33.2 & 5 & $132.8, \mathrm{CH}$ & 5 & $132.8, \mathrm{CH}$ & 5 & $33.8, \mathrm{CH}_{2}$ \\
\hline 8 & $130.2, \mathrm{CH}$ & 6 & $34.2, \mathrm{CH}_{2}$ & 6 & $34.2, \mathrm{CH}_{2}$ & 6 & 27.6, $\mathrm{CH}_{2}$ \\
\hline 9 & 130.7, CH & $7-14$ & 29.6-30.4, $\mathrm{CH}_{2}$ & $7-15$ & 29.6-30.5, $\mathrm{CH}_{2}$ & 7 & $33.3, \mathrm{CH}_{2}$ \\
\hline 10 & $32.1, \mathrm{CH}_{2}$ & 15 & $32.1, \mathrm{CH}_{2}$ & 16 & $35.6, \mathrm{CH}$ & 8 & $130.6, \mathrm{CH}$ \\
\hline $11-15$ & $29.5-30.4, \mathrm{CH}_{2}$ & 16 & $22.8, \mathrm{CH}_{2}$ & 17 & $30.6, \mathrm{CH}_{2}$ & 9 & $130.6, \mathrm{CH}$ \\
\hline 16 & $32.1, \mathrm{CH}_{2}$ & 17 & $14.2, \mathrm{CH}_{3}$ & 18 & 19.6, $\mathrm{CH}_{3}$ & 10 & 33.0, $\mathrm{CH}_{2}$ \\
\hline 17 & 22.9, $\mathrm{CH}_{2}$ & 18 & & 19 & $11.7, \mathrm{CH}_{3}$ & 11 & $30.4-29.5, \mathrm{CH}_{2}$ \\
\hline 18 & $14.3, \mathrm{CH}_{3}$ & $1^{\prime}$ & $175.8, \mathrm{C}$ & $1^{\prime}$ & $175.8, \mathrm{C}$ & 12 & $14.3, \mathrm{CH}_{3}$ \\
\hline $1^{\prime}$ & 175.5, C & $2^{\prime}$ & 72.6, $\mathrm{CH}$ & $2^{\prime}$ & 72.6, $\mathrm{CH}$ & $1^{\prime}$ & 175.1, C \\
\hline $2^{\prime}$ & $72.4, \mathrm{CH}$ & $3^{\prime}$ & 35.7, $\mathrm{CH}_{2}$ & $3^{\prime}$ & $35.7, \mathrm{CH}_{2}$ & $2^{\prime}$ & $72.8, \mathrm{CH}$ \\
\hline $3^{\prime}$ & $35.7, \mathrm{CH}_{2}$ & $4^{\prime}$ & 26.3, $\mathrm{CH}_{2}$ & $4^{\prime}$ & 26.3, $\mathrm{CH}_{2}$ & $3^{\prime}$ & $35.6, \mathrm{CH}_{2}$ \\
\hline $4^{\prime}$ & 26.3, $\mathrm{CH}_{2}$ & $5^{\prime}-12^{\prime}$ & 29.6-30.4, $\mathrm{CH}_{2}$ & $5^{\prime}-19^{\prime}$ & $29.6-30.4, \mathrm{CH}_{2}$ & $4^{\prime}$ & $26.8, \mathrm{CH}_{2}$ \\
\hline $5^{\prime}-12^{\prime}$ & $29.5-30.4, \mathrm{CH}_{2}$ & $13^{\prime}$ & $32.1, \mathrm{CH}_{2}$ & $20^{\prime}$ & $32.1, \mathrm{CH}_{2}$ & $5^{\prime}-12^{\prime}$ & $30.4-29.5, \mathrm{CH}_{2}$ \\
\hline $13^{\prime}$ & $32.1, \mathrm{CH}_{2}$ & $14^{\prime}$ & $22.8, \mathrm{CH}_{2}$ & $21^{\prime}$ & $22.8, \mathrm{CH}_{2}$ & $13^{\prime}$ & $32.1, \mathrm{CH}_{2}$ \\
\hline $14^{\prime}$ & 22.9, $\mathrm{CH}_{2}$ & $15^{\prime}$ & $14.2, \mathrm{CH}_{3}$ & $22^{\prime}$ & $14.2, \mathrm{CH}_{3}$ & $14^{\prime}$ & $22.8, \mathrm{CH}_{2}$ \\
\hline $15^{\prime}$ & $14.3, \mathrm{CH}_{3}$ & $1^{\prime \prime}$ & 105.6, CH & $1^{\prime \prime}$ & 105.6, CH & $15^{\prime}$ & $14.3, \mathrm{CH}_{3}$ \\
\hline $1^{\prime \prime}$ & $105.7, \mathrm{CH}$ & $2^{\prime \prime}$ & 75.1, CH & $2^{\prime \prime}$ & 75.1, CH & & \\
\hline $2^{\prime \prime}$ & 75.2, $\mathrm{CH}$ & $3^{\prime \prime}$ & 78.6, $\mathrm{CH}$ & $3^{\prime \prime}$ & 78.6, $\mathrm{CH}$ & & \\
\hline $3^{\prime \prime}$ & $78.5, \mathrm{CH}$ & $4^{\prime \prime}$ & $71.5, \mathrm{CH}$ & $4 "$ & 71.5, $\mathrm{CH}$ & & \\
\hline $4^{\prime \prime}$ & 71.6, $\mathrm{CH}$ & $5^{\prime \prime}$ & 78.6, $\mathrm{CH}$ & $5^{\prime \prime}$ & 78.6, $\mathrm{CH}$ & & \\
\hline $5^{\prime \prime}$ & 78.6, CH & $6^{\prime \prime}$ & $62.6, \mathrm{CH}_{2}$ & $6^{\prime \prime}$ & 62.6, $\mathrm{CH}_{2}$ & & \\
\hline $6^{\prime \prime}$ & $62.7, \mathrm{CH}_{2}$ & & & & & & \\
\hline
\end{tabular}<smiles>CCCCC=CCCCCC(O)C(N)CO</smiles>

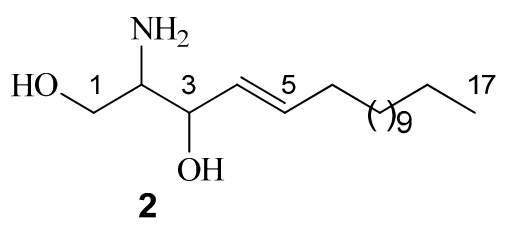<smiles>CCC(C)CCC=CC(O)C(N)CO</smiles>

3<smiles>CCCC=CCCCC(O)C(O)C(N)CO</smiles>

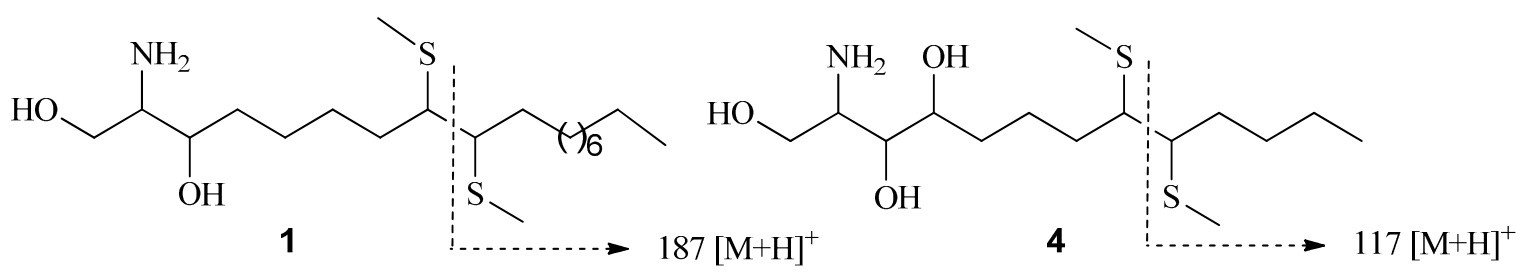

Figure 1. GC-MS analysis long-chain base (LCB) 1-4 and dimethyl disulfide (DMDS) derivatives of LCBs from $\mathbf{1}$ and $\mathbf{4}$. 

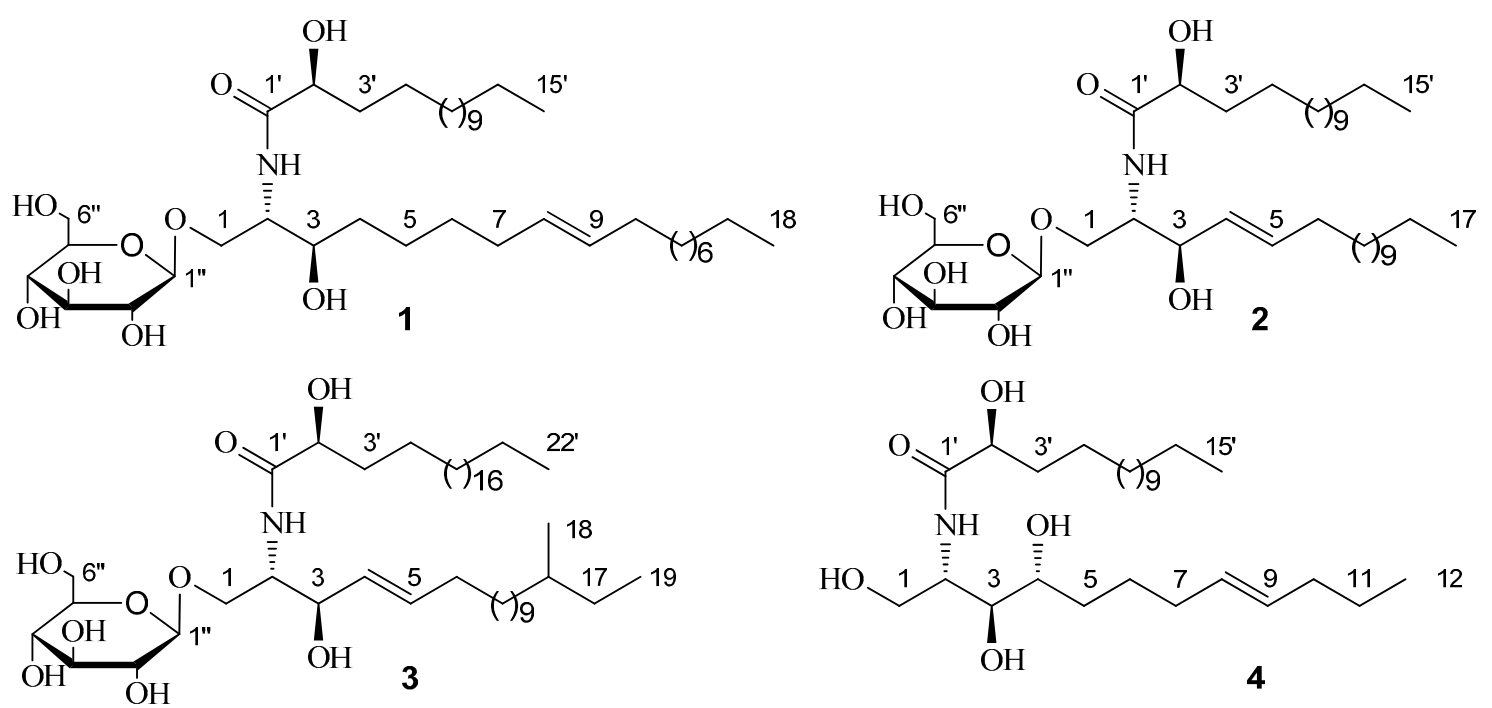

Figure 2. Structures of compounds $\mathbf{1}-\mathbf{4}$.

Compound 2 was obtained as white amorphous powder, $[\alpha]_{\mathrm{D}}^{22}=+14.8^{\circ}\left(c=0.40, \mathrm{C}_{5} \mathrm{H}_{5} \mathrm{~N}\right)$. The molecular formula was established as $\mathrm{C}_{38} \mathrm{H}_{73} \mathrm{NO}$, by HRESIMS $m / z 688.5358[\mathrm{M}+\mathrm{H}]^{+}$(calc. for 688.5364), indicating three degrees of unsaturation. Methanolysis experiment of 2 liberated D-glucose suggested that 2 was a D-glucoside. The IR absorption bands at $3405 \mathrm{~cm}^{-1}, 1634$ and $1536 \mathrm{~cm}^{-1}$, and $718 \mathrm{~cm}^{-1}$ originated from hydroxyl, amide, and methylene groups, respectively.

The ${ }^{1} \mathrm{H}$ - and ${ }^{13} \mathrm{C}-\mathrm{NMR}$ data of compound 2 were similar with $\mathbf{1}$, including the signals of a $\beta$-D-glucopyranosyl moiety. The position of olefinic bond in 2 was located at C- 4 and C- 5 by the spectra of HSQC, ${ }^{1} \mathrm{H}-{ }^{1} \mathrm{H}$ COSY, and HMBC. Methanolysis of 2 also obtained an FAM and an LCB. The FAM was determined as 2-hydroxypentadecanoic acid methyl ester by GC-MS analysis. The LCB of 2 was determined as 2-aminoheptadecenoic-4-ene-1,3-diol by GC-MS analysis (Figure 1). The specific rotation $[\alpha]_{\mathrm{D}}^{22}=-6.8^{\circ}\left(c 0.03, \mathrm{CHCl}_{3}\right)$ of the FAM confirmed that the absolute configuration of $\mathrm{C}-2^{\prime} R$, which is the same with 1 . The $2 S, 3 R$ stereochemistry was determined by comparing of the ${ }^{13} \mathrm{C}$-NMR data of C-2 and C-3 with those of in references [17,18]. The trans-configuration $(E)$ of the olefinic bond in 2 was determined by C-6 signal at $\delta \mathrm{C} 34.2$ in ${ }^{13} \mathrm{C}-\mathrm{NMR}$ spectrum [16]. The ${ }^{1} \mathrm{H}$ - and ${ }^{13} \mathrm{C}-\mathrm{NMR}$ data (Tables 1 and 2) were further assigned by the spectra of DEPT, HSQC, ${ }^{1} \mathrm{H}-{ }^{1} \mathrm{H}$ COSY, and HMBC. Consequently, 2 was established as 1-O- $\beta$-D-glucopyranosyl-(2S,3R,4E)-2-[(2'R)-2-hydroxylpentadecanoylamino]-4heptadecene-1,3-diol which is named as portulacerebroside $\mathrm{C}$ (Figure 2).

Compound 3 was obtained as white amorphous powder, $[\alpha]_{\mathrm{D}}^{22}=+8.2^{\circ}\left(c=0.15, \mathrm{C}_{5} \mathrm{H}_{5} \mathrm{~N}\right)$. The molecular formula $\mathrm{C}_{47} \mathrm{H}_{91} \mathrm{NO}_{9}$ was established for 3 by HRESIMS $m / z 814.6765[\mathrm{M}+\mathrm{H}]^{+}$(calc. for 814.6772), indicating three degrees of unsaturation. Methanolysis experiment of 3 liberated D-glucose suggested that 3 was a D-glucoside. The IR absorption bands at $3412 \mathrm{~cm}^{-1}, 1638$ and $1530 \mathrm{~cm}^{-1}$, and $722 \mathrm{~cm}^{-1}$ originated from hydroxyl, amide, and methylene groups, respectively.

The ${ }^{1} \mathrm{H}$ - and ${ }^{13} \mathrm{C}-\mathrm{NMR}$ data of compound $\mathbf{3}$ were similar with $\mathbf{2}$ and the main difference lies in the methenyl group signal at $\delta_{\mathrm{C}} 35.6$ and methyl group signals at $\delta_{\mathrm{C}} 11.7$ and 19.6 in ${ }^{13} \mathrm{C}-\mathrm{NMR}$ spectrum of $\mathbf{3}$, which indicated the presence of a branched methyl group in $\mathbf{3}$. To determine the position of the branched methyl group, the 1D-TOCSY spectrum was used and correlations of $\delta_{\mathrm{H}} 4.22(1 \mathrm{H}, \mathrm{m}, \mathrm{H}-1)$ with $5.86(1 \mathrm{H}, \mathrm{m}, \mathrm{H}-4), 0.88(3 \mathrm{H}, \mathrm{d}, J=6.4 \mathrm{~Hz})$, and $0.86,\left(3 \mathrm{H}, \mathrm{t}, J=6.4 \mathrm{~Hz}, 19-\mathrm{CH}_{3}\right)$ could be 
observed. Therefore, the branched methyl group was located in the LCB. Other methods to determine the structure of 3 were the same with 2 . The ${ }^{1} \mathrm{H}$ - and ${ }^{13} \mathrm{C}-\mathrm{NMR}$ data (Tables 1 and 2) were further assigned by the spectra of DEPT, HSQC, ${ }^{1} \mathrm{H}-{ }^{1} \mathrm{H}$ COSY, and HMBC. Consequently, 3 was established as 1-O- $\beta$-D-glucopyranosyl-(2S,3R,4E)-2-[(2'R)-2-hydroxyldocosanamideamino]-16-methyl-4-nonadecene1,3-diol which is named as portulacerebroside D (Figure 2).

Compound 4 was obtained as white amorphous powder, $[\alpha]_{D}^{22}=+9.5^{\circ}\left(c=0.30, \mathrm{C}_{5} \mathrm{H}_{5} \mathrm{~N}\right)$. The molecular formula $\mathrm{C}_{27} \mathrm{H}_{53} \mathrm{NO}_{5}$ was established for 1 by HRESIMS $m / z 472.3995[\mathrm{M}+\mathrm{H}]^{+}$(calc. for 472.4002), indicating two degrees of unsaturation. The IR absorption bands at $3401 \mathrm{~cm}^{-1}, 1621$ and $1533 \mathrm{~cm}^{-1}$, and $723 \mathrm{~cm}^{-1}$ originated from hydroxyl, amide, and methylene groups, respectively.

The ${ }^{1} \mathrm{H}$ - and ${ }^{13} \mathrm{C}-\mathrm{NMR}$ spectra (Tables 1 and 2) of 4 showed characteristics of a sphingosine-type ceramide with a 2-hydroxy fatty acid fraction. Methanolysis of 4 obtained an FAM and an LCB. The FAM was determined as 2-hydroxypentadecanoic acid methyl ester by GC-MS analysis. The 1D-TOCSY spectrum of 4 showed a correlation between $\delta_{\mathrm{H}} 4.27(1 \mathrm{H}, \mathrm{m}, \mathrm{H}-4)$ and $5.52(2 \mathrm{H}, \mathrm{m}, \mathrm{H}-8,9)$, which suggested the olefinic bond was located in the LCB. To determine the location of the olefinic bond in LCB, the DMDS derivatives of LCB was analyzed by ESIMS and characteristic fragment ion of $m / z 117[\mathrm{M}+\mathrm{H}]^{+}$was obtained. Therefore, the olefinic bond was located at C-8 and C-9. The LCB was further determined as 2-aminododecane-8-ene-1,3,4-triol by GC-MS analysis (Figure 1). The specific rotation $[\alpha]_{\mathrm{D}}^{22}=-4.7^{\circ}\left(c 0.02, \mathrm{CHCl}_{3}\right)$ of the FAM confirmed that the absolute configuration of $\mathrm{C}-2^{\prime} R[13]$. The $2 S, 3 S$, and $4 R$ stereochemistry was determined by comparing of the ${ }^{13} \mathrm{C}-\mathrm{NMR}$ data of $\mathrm{C}-2, \mathrm{C}-3$, and C-4 with those of in reference [19]. The trans-configuration $(E)$ of the olefinic bond in 4 was determined by signals at $\delta_{\mathrm{C}} 33.3 / 33.0$ of the two carbons next to the olefinic bond in ${ }^{13} \mathrm{C}-\mathrm{NMR}$ spectrum [16]. The ${ }^{1} \mathrm{H}$ - and ${ }^{13} \mathrm{C}-\mathrm{NMR}$ data (Tables 1 and 2) were further assigned by the spectra of DEPT, HSQC, ${ }^{1} \mathrm{H}-{ }^{1} \mathrm{H}$ COSY, and $\mathrm{HMBC}$ and 4 was established as $(2 S, 3 S, 4 R, 8 E)-2-\left[\left(2^{\prime} R\right)-2-\right.$ hydroxylpentadecanoylamino]-8-dodecene-1,3,4-triol which is named as portulaceramide A (Figure 2).

The known compounds were identified as friedelin (6) [20], 3-acetylaleuritolic acid (7) [21], $4 \alpha$-methyl-3 $\beta$-hydroxylfriedelan (8) [22], cycloartenol (9) [23], and lupeol (10) [24] by comparing their NMR spectroscopic and physical data with the literature values (Figure 3 ).
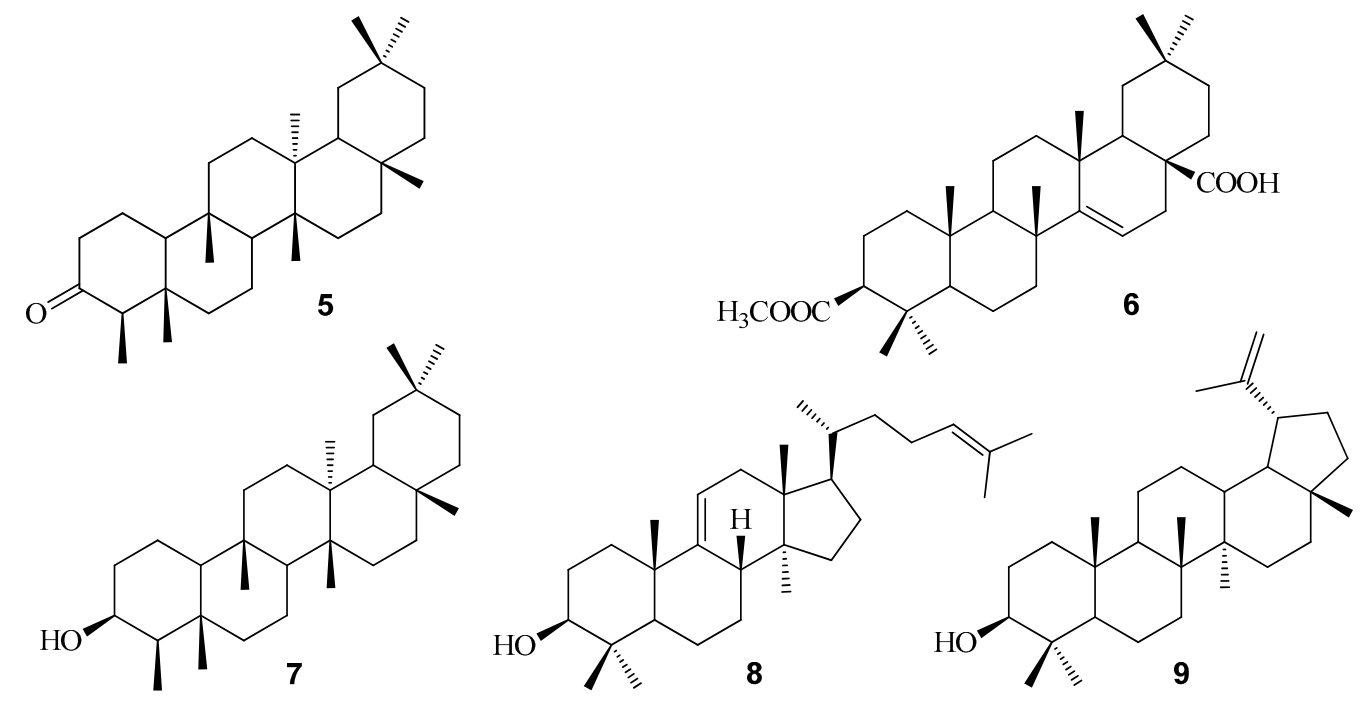

Figure 3. Structures of compounds 5-9. 
The antibacterial activities of compounds 1-9 against Escherichia coli (E. coli), Staphylococcus aureus (S. aureus), Shigella flexneri (S. flexneri), and Salmonella typhi (S. typhi) were investigated. Minimal inhibitory concentrations (MICs) and minimal bactericidal concentrations (MBCs) were determined. Compounds 1-4 showed significant antibacterial activity on common enteropathogenic bacteria in vitro (Table 3), while other compounds did not show any antibacterial effects on the enteropathogenic bacteria at the tested concentration (data not shown). The structures of compounds 1-4 involve a sphingoid base and an amide-linked fatty acyl chain. The amphipathic molecules exhibit diverse biological activity, including broad antibacterial activities against both Gram positive and negative bacteria in this study.

Table 3. The minimal inhibitory concentrations (MICs) $\left(\mathrm{mg} \cdot \mathrm{mL}^{-1}\right)$ and minimal bactericidal concentrations $(\mathrm{MBCs})\left(\mathrm{mg} \cdot \mathrm{mL}^{-1}\right)$ of compounds $\mathbf{1}-\mathbf{4}$.

\begin{tabular}{ccccccccccc}
\hline \multirow{2}{*}{ Strains } & \multicolumn{4}{c}{ MICs (SD = 0) } & \multicolumn{4}{c}{ MBCs (SD = 0) } \\
\cline { 2 - 11 } & $\mathbf{1} *$ & $\mathbf{2} *$ & $\mathbf{3} *$ & $\mathbf{4} *$ & Amoxicillin & $\mathbf{1}$ & $\mathbf{2}$ & $\mathbf{3}$ & $\mathbf{4}$ & Amoxicillin \\
\hline E. coli & 0.1875 & 0.1875 & 0.1875 & 0.375 & $2.34 \times 10^{-2}$ & 0.25 & 0.25 & 0.25 & 0.50 & $3.12 \times 10^{-2}$ \\
S. aureus & 0.1875 & 0.1875 & 0.1875 & 0.375 & $1.17 \times 10^{-2}$ & 0.50 & 0.50 & 0.50 & 0.50 & $1.56 \times 10^{-2}$ \\
S. flexneri & 0.1875 & 0.1875 & 0.1875 & 0.1875 & $5.85 \times 10^{-3}$ & 0.25 & 0.25 & 0.25 & 0.25 & $3.90 \times 10^{-3}$ \\
S. typhi & 0.1875 & 0.1875 & 0.1875 & 0.375 & $1.17 \times 10^{-2}$ & 0.25 & 0.25 & 0.25 & 0.50 & $7.80 \times 10^{-3}$ \\
\hline
\end{tabular}

Key: Effects of the tested compounds on enteropathogenic bacteria. MICs and MBCs were expressed as mean $\pm \mathrm{SD}(n=4)$ of three independent experiments. MIC was expressed as the mean concentration between the well showing growth and that showing no growth. The MBC was expressed as the lowest concentration of the compounds showing no any bacterial growth after incubating for $20 \mathrm{~h}$; * Significant difference $(p<0.01)$ compared the MIC values of compounds 1-4 with 5-9 (MIC $>16.0 \mathrm{mg} \cdot \mathrm{mL}^{-1}$, data not shown), respectively.

\section{Experimental Section}

\subsection{General}

The NMR spectra were measured on Bruker AVANCE $400 \mathrm{MHz}$ NMR instrument (Bruker SpectroSpin, Karlsruhe, Germany), and chemical shifts are given as $\delta$ (ppm) while the coupling constants are given in Hz. Xero Q Tof MS spectrometer (Waters, Milford, MA, USA) was used to measure and analysis the HRESIMS data. Volatile derivatives from compounds were analyzed on a GC-MS (Angilent, California, CA, USA) instrument. Waters 2535 instrument coupled with a Waters Sunfire prep C18 OBD (19 $\times 250$ mm i.d.) column, a UV-2998 (Waters, MA, USA), and RI-2414 detector as a Preparative HPLC (Waters, MA, USA) was used to prepare compounds. FTIR-8400S (Shimadzu, Kyoto, Japan) was used to record the IR Spectra data; Column chromatographies including Macroporous resin (AB-8 Crosslinked Polystyrene, Nankai Chemical Plant, Tianjin, China), silica gel (200-300 mesh, Haiyang Chemical Group Co. Ltd., Qingdao, China), and ODS-A (120A, 50 mm; YMC, Kyoto, Japan) were also employed. A microplate reader (BMG FLUOStar OPTIMA, Ortenberg, Germany) was used to monitor the growth of the bacterial strains. 


\subsection{Bacterial Strains and the Preparation of Inoculums}

The bacterial strains of E. coli (ATCC25922), S. aureus (ATCC25923), S. flexneri (ATCC12022), and S. typhi (ATCC14028) from American Type Culture Collection were provided by Department of Microbiology and Immunology, Heilongjiang university of Chinese medicine. Strains from refrigerated stock cultures were inoculated into common agar plate and incubated at $37{ }^{\circ} \mathrm{C}$ for $18 \mathrm{~h}$. The bacteria were activated in nutrient broth and incubated at $37^{\circ} \mathrm{C}$ for another $18 \mathrm{~h}$. The concentrations of strains for antibacterial test in vitro were $5 \times 10^{5} \mathrm{CFU} \cdot \mathrm{mL}^{-1}$.

\subsection{Plant Materials}

We collected the aerial part of P. oleracea from the Dongfanghong Forestry Agency (Jixi, China) and identified by Lianjie Su of Heilongjiang University of Chinese Medicine. The voucher specimen (No. 20130814) is deposited at the Herbarium of Heilongjiang University of Chinese Medicine, China.

\subsection{Extraction and Isolation}

The dried P. oleracea $(15.0 \mathrm{~kg})$ extracted with $70 \%$ EtOH under reflux $(2 \times 120 \mathrm{~L})$ for $2 \mathrm{~h}$. The $70 \% \mathrm{EtOH}$ extract (1770 g) was suspended in $\mathrm{H}_{2} \mathrm{O}(20 \mathrm{~L})$, and successively extracted with petroleum ether $\left(60-90{ }^{\circ} \mathrm{C}\right)$, EtOAc and $n$-butanol, respectively. Solvent was removed to give petroleum ether extract (125.3 g), EtOAc extract (173.7 g), $n$-butanol extract (184.8 g), and remained water extract $(1267.2 \mathrm{~g})$. The EtOAc extract is the antibacterial effective fraction as previous study. The EtOAc fraction (150.0 g) was repeatedly column chromatographed on silica gel with a gradient of $\mathrm{CH}_{2} \mathrm{Cl}_{2} / \mathrm{MeOH}$ (40:1 to 0:1) as eluents to afford seven fractions: $\mathrm{F}_{1}-\mathrm{F}_{7} . \mathrm{F}_{2}$ (13.2 g) continued silica gel chromatography and eluted with petroleum ether/EtOAc (15:1 to 1:1) to afford sub-fractions $\mathrm{A}_{1}-\mathrm{A}_{4}$. Compounds 4 (53 mg) and 9 (37 mg) were obtained by silica gel chromatography of the sub-fraction

$\mathrm{A}_{2}$ (3.5 g) elution with petroleum ether/EtOAc (8:1), $\mathrm{F}_{3}(25.7 \mathrm{~g})$ was subjected to column chromatography on silica gel with $\mathrm{CH}_{2} \mathrm{Cl}_{2} / \mathrm{MeOH}(30: 1$ to $10: 1)$ to afford sub-fractions $\mathrm{B}_{1}-\mathrm{B}_{5}$. $\mathrm{B}_{3}(6.5 \mathrm{~g})$ was separated on silica gel chromatography and eluted with $\mathrm{CH}_{2} \mathrm{Cl}_{2} / \mathrm{MeOH}$ (40:1 to 15:1) and further purified by preparative HPLC on a Hypersil-ODS II column $(10 \mu \mathrm{m}, 20 \times 300 \mathrm{~mm}$, flow rate $8 \mathrm{~mL} / \mathrm{min})$ with $\mathrm{MeOH} / \mathrm{H}_{2} \mathrm{O}(48 \%$ and $52 \%)$ to afford compound $5\left(43 \mathrm{mg}, t_{\mathrm{R}}=17 \mathrm{~min}\right), 7\left(38 \mathrm{mg}, t_{\mathrm{R}}=24 \mathrm{~min}\right)$, and 8 (33 mg, $\left.t_{\mathrm{R}}=28 \mathrm{~min}\right)$. F5 (32.6 g) was subjected to column chromatography on silica gel with $\mathrm{CH}_{2} \mathrm{Cl}_{2} / \mathrm{MeOH}(30: 1-8: 1)$ to produce sub-fractions $\mathrm{C}_{1}-\mathrm{C}_{5}$. The $\mathrm{C}_{3}$ (4.0 g) was repeatedly column chromatographed on silica gel with $\mathrm{CH}_{2} \mathrm{Cl}_{2} / \mathrm{MeOH}(15: 1$ to $6: 1)$ as eluents to afford 2 (40 mg) and 6 (21 mg). The $\mathrm{C}_{4}(5.9 \mathrm{~g})$ was repeatedly column chromatographed on silica gel with $\mathrm{CH}_{2} \mathrm{Cl}_{2} / \mathrm{MeOH}$ (15:1 to 6:1) as eluents and followed separated on column chromatography Sephadex LH-20 with MeOH as eluent to afford $\mathbf{1}(32 \mathrm{mg})$ and $\mathbf{3}(37 \mathrm{mg})$.

Portulacerebroside B (1): white amorphous powder, $[\alpha]_{\mathrm{D}}^{22}=+13.3^{\circ}\left(c=0.52, \mathrm{C}_{5} \mathrm{H}_{5} \mathrm{~N}\right)$; IR $(\mathrm{KBr}) v_{\max }$ 3420, 2933, 2837, 1645, 1542, 1471, 1280, 1158, 1082, $722 \mathrm{~cm}^{-1}$; ESIMS m/z 702 (100) $[\mathrm{M}+\mathrm{H}]^{+}$; HRESIMS $[\mathrm{M}+\mathrm{H}]^{+} \mathrm{m} / \mathrm{z} 702.5516$, calc. 702.5520 for $\mathrm{C}_{39} \mathrm{H} 75 \mathrm{NO} 9 \mathrm{H} ;{ }^{1} \mathrm{H}$ - and ${ }^{13} \mathrm{C}-\mathrm{NMR}$ data, see Tables 1 and 2. 
Portulacerebroside $C$ (2): white amorphous powder; $[\alpha]_{\mathrm{D}}^{22}=+14.8^{\circ}\left(c=0.40, \mathrm{C}_{5} \mathrm{H}_{5} \mathrm{~N}\right)$; IR $(\mathrm{KBr}) v_{\max }$ 3405, 2927, 2832, 1634, 1536, 1468, 1155, $718 \mathrm{~cm}^{-1}$; ESIMS $m / z 688(100)[\mathrm{M}+\mathrm{H}]^{+}$; HRESIMS $[\mathrm{M}+\mathrm{H}]^{+} \mathrm{m} / z 688.5358$ calc. 688.5364 for $\mathrm{C}_{38} \mathrm{H}_{73} \mathrm{NO} 9{ }_{9} \mathrm{H} ;{ }^{1} \mathrm{H}$ - and ${ }^{13} \mathrm{C}-\mathrm{NMR}$ data, see Tables 1 and 2.

Portulacerebroside D (3): white amorphous powder; $[\alpha]_{\mathrm{D}}^{22}=+8.2^{\circ}\left(c=0.15, \mathrm{C}_{5} \mathrm{H}_{5} \mathrm{~N}\right)$; IR $(\mathrm{KBr}) v_{\max }$ 3412, 2941, 2838, 1638, 1530, 1455, 1162, $722 \mathrm{~cm}^{-1}$; ESIMS $m / z 814(100)[\mathrm{M}+\mathrm{H}]^{+}$; HRESIMS $[\mathrm{M}+\mathrm{H}]^{+} \mathrm{m} / \mathrm{z} 814.6765$ calc. 814.6772 for $\mathrm{C}_{57} \mathrm{H}_{91} \mathrm{NO} 9{ }_{9} \mathrm{H} ;{ }^{1} \mathrm{H}$ - and ${ }^{13} \mathrm{C}-\mathrm{NMR}$ data, see Tables 1 and 2 .

Portulaceramide A (4): white amorphous powder; $[\alpha]_{\mathrm{D}}^{22}=+9.5^{\circ}\left(c=0.30, \mathrm{C}_{5} \mathrm{H}_{5} \mathrm{~N}\right)$; IR $(\mathrm{KBr}) v_{\max } 3401$, 3212, 2921, 1621, 1533, 1474, $723 \mathrm{~cm}^{-1}$; ESIMS $m / z 472(100)[\mathrm{M}+\mathrm{H}]^{+}$; HRESIMS $[\mathrm{M}+\mathrm{H}]^{+} \mathrm{m} / z$ 472.3995 calc. 472.4002 for $\mathrm{C}_{27} \mathrm{H}_{53} \mathrm{NO}_{5} \mathrm{H} ;{ }^{1} \mathrm{H}$ - and ${ }^{13} \mathrm{C}-\mathrm{NMR}$ data, see Tables 1 and 2.

\subsection{Methanolysis of $\mathbf{1}-\mathbf{4}$}

Methanolysis experiment of $\mathbf{1}$ was conducted as previous studies [25,26]. Briefly, compound $\mathbf{1}$ $(5.0 \mathrm{mg})$ was refluxed with $5 \% \mathrm{HCl}$ in $82 \%$ aqueous $\mathrm{MeOH}(20 \mathrm{~mL})$ for $18 \mathrm{~h}$. After that the reaction mixture was extracted with $n$-hexane and the fatty acid methyl ester (FAME) was obtained as a white amorphous powder, $[\alpha]_{\mathrm{D}}^{22}=-5.8^{\circ}\left(c 0.02, \mathrm{CHCl}_{3}\right)$. The FAME was analyzed by GC-MS and the characteristic fragment ions $\left(m / z 286[\mathrm{M}]^{+}, 228\left[\mathrm{M}-\mathrm{COOMe}^{+}\right)\right.$were obtained. Therefore, the FAME of 1 was determined as $2 R$-hydroxypentadecanoic acid methyl ester. The monosaccharide of 1 was determined as D-glucose $\left(t_{\mathrm{R}}=7.26 \mathrm{~min}\right)$ by analyzing the remained solution on a GC-MS. The remained solution was evaporated $\mathrm{MeOH}$ followed by adjusting $\mathrm{pH} 9$ with aqueous ammonia. The solution was extracted with $\mathrm{Et}_{2} \mathrm{O}$ and the $\mathrm{Et}_{2} \mathrm{O}$ layer was dried to obtain the long-chain base (LCB) of $\mathbf{1}$. The LCB was analyzed by ESIMS to obtain the fragment ions of $m / z 300[\mathrm{M}+\mathrm{H}]^{+}$and $282\left[\mathrm{M}-\mathrm{H}_{2} \mathrm{O}+\mathrm{H}\right]^{+}$. Thus, the LCB of 1 was determined as 2-aminooctadec-8-ene-1,3-diol (Figure 1).

Methanolysis of $\mathbf{2}$ was performed by the same method for $\mathbf{1}$ and an FAME and an LCB was obtained respectively. The FAME was a white amorphous powder, $[\alpha]_{\mathrm{D}}^{22}=-6.8^{\circ}\left(\mathrm{c} 0.03, \mathrm{CHCl}_{3}\right)$, and the characteristic fragment ions $\left(\mathrm{m} / \mathrm{z} 286[\mathrm{M}]^{+}, 228[\mathrm{M}-\mathrm{COOMe}]^{+}\right)$were obtained by GC-MS analysis. Therefore, the FAME of $\mathbf{2}$ was determined as $2 R$-hydroxypentadecanoic acid methyl ester. The monosaccharide of $\mathbf{2}$ was also determined as D-glucose. The LCB of $\mathbf{2}$ was analyzed by ESIMS to obtain the fragment ions of $m / z 286[\mathrm{M}+\mathrm{H}]^{+}$and $268\left[\mathrm{M}-\mathrm{H}_{2} \mathrm{O}+\mathrm{H}\right]^{+}$. Thus, the LCB of 2 was determined as 2-aminoheptadecenoic-4-ene-1,3-diol (Figure 1).

Methanolysis of $\mathbf{3}$ was performed by the same method for $\mathbf{1}$ and an FAME and an LCB was also obtained respectively. The FAME was a white amorphous powder, $[\alpha]_{\mathrm{D}}^{22}=-3.8^{\circ}\left(c 0.02, \mathrm{CHCl}_{3}\right)$, and the characteristic fragment ions $\left(\mathrm{m} / \mathrm{z} 384[\mathrm{M}]^{+}, 326[\mathrm{M}-\mathrm{COOMe}]^{+}\right)$were obtained by GC-MS analysis. Therefore, the FAME of $\mathbf{3}$ was determined as $2 R$-hydroxydocosanoic acid methyl ester. The monosaccharide of $\mathbf{3}$ was also determined as D-glucose. The LCB of $\mathbf{3}$ was analyzed by ESIMS to obtain the fragment ions of $m / z 314[\mathrm{M}+\mathrm{H}]^{+}$and $296\left[\mathrm{M}-\mathrm{H}_{2} \mathrm{O}+\mathrm{H}\right]^{+}$. Thus, the LCB of 3 was determined as 2-aminononadecane-4-ene-1,3-diol (Figure 1).

Methanolysis of 4 was also performed to obtain the FAME and LCB. The FAME was a white amorphous powder, $[\alpha]_{\mathrm{D}}^{22}=-4.7^{\circ}\left(\mathrm{c} 0.02, \mathrm{CHCl}_{3}\right)$, and the characteristic fragment ions $\left(\mathrm{m} / \mathrm{z} 286[\mathrm{M}]^{+}\right.$, $228[\mathrm{M}-\mathrm{COOMe}]^{+}$) were obtained by GC-MS analysis. Therefore, the FAME of 4 was determined as $2 R$-hydroxypentadecanoic acid methyl ester. The LCB of $\mathbf{4}$ was analyzed by ESIMS to obtain the 
fragment ions of $m / z 232[\mathrm{M}+\mathrm{H}]^{+}, 214\left[\mathrm{M}-\mathrm{H}_{2} \mathrm{O}+\mathrm{H}\right]^{+}, 196\left[\mathrm{M}-2 \mathrm{H}_{2} \mathrm{O}+\mathrm{H}\right]^{+}$and $178\left[\mathrm{M}-3 \mathrm{H}_{2} \mathrm{O}+\mathrm{H}\right]^{+}$. Thus, the LCB of 4 was determined as 2-aminododecane-8-ene-1,3,4-triol (Figure 1).

\subsection{Dimethyl Disulfide Derivative of LCBs from 1 and $\mathbf{4}$}

According to the reference [18], LCBs from 1 and 4 (0.5 $\mathrm{mg})$ were dissolved in dimethyl disulfide (DMDS, $0.2 \mathrm{~mL})$, respectively, and then iodine $(1 \mathrm{mg}$ ) was added into the solutions. The mixtures were stored in a small-volume sealed vial at $60{ }^{\circ} \mathrm{C}$ for $40 \mathrm{~h}$. The reaction was ended with aqueous $\mathrm{Na}_{2} \mathrm{~S}_{2} \mathrm{O}_{3}$ $(5 \%)$, and then we extracted the mixtures with $n$-hexane $(0.3 \mathrm{~mL})$. The extracts were concentrated respectively to give the DMDS derivatives of LCBs from $\mathbf{1}$ and $\mathbf{4}$. The derivatives were analyzed by ESIMS. As a result, the characteristic fragment ions of $m / z 187[\mathrm{M}+\mathrm{H}]^{+}$for $\mathbf{1}$ and $117[\mathrm{M}+\mathrm{H}]^{+}$for 4 were observed respectively.

\subsection{Antibacterial Test in Vitro}

\subsubsection{Compounds 1-9 Serial Dilution}

A microdilution method was used to determine the MICs of the compounds on 96-well cultivated plates according to the previous report [27]. The compounds 1-9 were dissolved in nutrient broth with $10 \%$ DMSO and $32.0 \mathrm{mg} \cdot \mathrm{mL}^{-1}$ solutions ( $\mathrm{pH} 7.2$ ) were obtained, respectively. There were 12 wells in each row of a microplate, to each of the first ones we added $100 \mu \mathrm{L}$ compound solution, and to the remaining 11 wells we added $100 \mu \mathrm{L}$ broth culture. For serial dilution, $100 \mu \mathrm{L}$ each compound solution was added into the second well and then $100 \mu \mathrm{L}$ was sequentially transferred to the following wells until the 10th well. The last two wells served as growth control and sterility check. After that, $100 \mu \mathrm{L}$ of inoculum was added into each well except the last well in which $100 \mu \mathrm{L}$ broth was added instead. Amoxicillin was used as a positive drug.

\subsubsection{Determination of MICs and MBCs}

The growth of the bacterial strains in the microplates was monitored at $37{ }^{\circ} \mathrm{C}$ for $20 \mathrm{~h}$ using a microplate reader. Standard antibacterial agent amoxicillin was also screened under identical conditions for comparison. Considering the role of DMSO, the same experiment was carried out with 10\% DMSO and showed no activity against any bacterial strains. MIC was expressed as the mean concentration between the well showing growth and that showing no growth.

After MIC testing, the microplates set up for the MICs determination were used to determine the MBC as described previously [28]. For each well showing no bacterial growth, the entire volume was spread onto nutrient agar plates and subcultured. The MBC was defined as the lowest concentration of the compounds showing no bacterial growth after incubating for $20 \mathrm{~h}$.

\section{Conclusions}

We investigated the chemical constituents of $P$. oleracea based on its antibacterial activity and nine compounds were obtained, including three new cerebrosides and a new ceramide. The structures of new compounds were identified as 1-O- $\beta$-D-glucopyranosyl- $(2 S, 3 R, 8 E)-2-\left[\left(2^{\prime} R\right)-2-\right.$ 
hydroxylpentadecanoylamino]-8-octadecene-1,3-diol (1), 1-O- $\beta$-D-glucopyranosyl-(2S,3R,4E)-2-[(2'R)-2hydroxylpentadecanoyl-amino]-4-heptadecene-1,3-diol (2), 1-O- $\beta$-D-glucopyranosyl- $(2 S, 3 R, 4 E)-2-\left[\left(2^{\prime} R\right)-\right.$ 2-hydroxyl-docosanamideamino]-16-methyl-4-nonadecene-1,3-diol (3), and (2S,3S,4R,8E)-2-[(2'R)-2hydroxyl-pentadecanoylamino]-8-dodecene-1,3,4-triol (4), respectively. Antibacterial tests in vitro showed that new compounds could significantly inhibit or kill the common enteropathogenic bacteria, which might contribute to revealing the usefullness of $P$. oleracea as a treatment for bacillary dysentery.

\section{Acknowledgments}

This research was supported by the Program of Natural Science Foundation of Heilongjiang (No. H2013012).

\section{Author Contributions}

Xia Lei and Jianmin Li conceived and designed the experiments; Xia Lei performed the experiments; Bin Liu and Ning Zhang analyzed the data; Xia Lei contributed reagents/materials/analysis tools; Haiyang Liu wrote the paper.

\section{Conflicts of Interest}

The authors declare no conflict of interest.

\section{References and Notes}

1. Liu, X.F.; Zheng, C.G.; Shi, H.G.; Tang, G.S.; Wang, W.Y.; Zhou, J.; Dong, L.W. Ethanol extract from Portulaca oleracea L. attenuated acetaminophen-induced mice liver injury. Am. J. Transl. Res. 2015, 7, 309-318.

2. Zhou, Y.X.; Xin, H.L.; Rahman, K.; Wang, S.J.; Peng, C.; Zhang, H. Portulaca oleracea L.: A review of phytochemistry and pharmacological effects. Biomed. Res. Int. 2015, 2015, 925631, doi:10.1155/2015/925631.

3. Behravan, J.; Mosafa, F.; Soudmand, N.; Taghiabadi, E.; Razavi, B.M.; Karimi, G. Protective effects of aqueous and ethanolic extracts of Portulaca oleracea L. aerial parts on $\mathrm{H}_{2} \mathrm{O}_{2}$-induced DNA damage in lymphocytes by comet assay. J. Acupunct. Meridian Stud. 2011, 4, 193-197.

4. Xin, H.L.; Hou, Y.H.; Xu, Y.F.; Yue, X.Q.; Li, M.; Lu, J.C.; Ling, C.Q. Portulacerebroside A: New cerebroside from Portulaca oleracea L. Chin. J. Nat. Med. 2008, 6, 401-403.

5. Elkhayat, E.S.; Ibrahim, S.R.; Aziz, M.A. Portulene, a new diterpene from Portulaca oleracea. J. Asian Nat. Prod. Res. 2008, 10, 1039-1043.

6. Chan, B.C.; Han, X.Q.; Lui, S.L.; Wong, C.W.; Wang, T.B.; Cheung, D.W.; Cheng, S.W.; Ip, M.; Han, S.Q.; Yang, X.S.; et al. Combating against methicillin-resistant Staphylococcus aureus-Two fatty acids from Purslane ( Portulaca oleracea L.) exhibit synergistic effects with erythromycin. J. Pharm. Pharmacol. 2015, 67, 107-116.

7. Noreen, S.; Hussain, I.; Tariq, M.I.; Ijaz, B.; Iqbal, S.; Qamar-U1, Z.; Ashfaq, U.A.; Husnain, T. Portulaca oleracea L. as a prospective candidate inhibitor of hepatitis C virus NS3 serine protease. Viral Immunol. 2015, 28, 282-289. 
8. Al-Sheddi, E.S.; Farshori, N.N.; Al-Oqail, M.M.; Musarrat, J.; Al-Khedhairy, A.A.; Siddiqui, M.A. Portulaca oleracea seed oil exerts cytotoxic effects on human liver cancer (HepG2) and human lung cancer (A-549) cell lines. Asian Pac. J. Cancer Prev. 2015, 16, 3383-3387.

9. Chan, K.; Islam, M.W.; Kamil, M.; Radhakrishnan, R.; Zakaria, M.N.; Habibullah, M.; Attas, A. The analgesic and anti-inflammatory effects of Portulaca oleracea L. subsp. sativa (haw.) Celak. J. Ethnopharmacol. 2000, 73, 445-451.

10. Radhakrishnan, R.; Zakaria, M.N.; Islam, M.W.; Chen, H.B.; Kamil, M.; Chan, K.; Al-Attas, A. Neuropharmacological actions of Portulaca oleraceae L. v. sativa (hawk). J. Ethnopharmacol. 2001, 76, 171-176.

11. Abdel Moneim, A.E. The neuroprotective effects of purslane (Portulaca oleracea) on rotenone-induced biochemical changes and apoptosis in brain of rat. Neurol. Disord. Drug Targets 2013, 12, 830-841.

12. Kim, J.Y.; Oh, H.M.; Kwak, S.C.; Cheon, Y.H.; Lee, M.S.; Rho, M.C.; Oh, J. Purslane suppresses osteoclast differentiation and bone resorbing activity via inhibition of Akt/GSK3 $\beta$-c-Fos-NFATc1 signaling in vitro and prevents lipopolysaccharide-induced bone loss in vivo. Biol. Pharm. Bull. 2015, 38, 66-74.

13. Shibuya, H.; Kawashima, K.; Sakagami, M.; Shimomura, M.; Ohashi, K.; Kitagawa, I. Sphingolipids and glycerolipids. I.: Chemical structures and ionophoretic activities of soyacerebrosides I and II form soybean. Chem. Pharm. Bull. 1990, 38, 2933-2938.

14. Costantino, V.; Fattorusso, E.; Mangoni, A. Glycolipids from sponges. Part 9: Plakoside C and D, two further prenylated glycosphingolipids from the marine sponge Ectyoplasia ferox. Tetrahedron 2000, 56, 5953-5957.

15. Kang, S.S.; Kim, J.S.; Son, K.H.; Kim, H.P.; Chang, H.W. Cyclooxygenase-2 inhibitory cerebrosides from Phytolaccae Radix. Chem. Pharm. Bull. 2001, 49, 321-323.

16. Ling, T.J.; Xia, T.; Wan, X.C.; Li, D.X.; Wei, X.Y. Cerebrosides from the Roots of Serratula chinensis. Molecules 2006, 11, 677-683.

17. Yamada, K.; Wada, N.; Onaka, H.; Matsubara, R.; Isobe, R.; Inagaki, M.; Higuchi, R. Constituents of holothuroidea, isolation of ante-iso type regio isomer on long chain base moiety of glucocerebroside from the sea cucumber Holothuria leucospilota. Chem. Pharm. Bull. 2005, 53, 788-791.

18. Satoshi, K.; Kazufumi, N.; Masanori, I.; Ryuichi, H. Isolation and structure determination of six glucocerebrosides from the starfish Luidia maculate. Chem. Pharm. Bull. 2002, 50, 1091-1096.

19. Yang, N.Y.; Ren, D.C.; Duan, J.A.; Xu, X.H.; Xie, N.; Tian, L.J. Ceramides and cerebrosides from Ligusticum chuanxiong Hort. Helv. Chim. Acta 2009, 92, 291-297.

20. Chen, C.; Wei, G.; Zhu, H.; Guo, Y.; Li, X.N.; Zhang, J.; Liu, Y.; Yao, G.; Luo, Z.; Xue, Y.; et al. A new 3,4- seco- oleanane-type triterpenoid with an unusual enedione moiety from Hypericum ascyron. Fitoterapia 2015, 103, 227-230.

21. Supaluk, P.; Saowapa, S.; Apilak, W.; Ratana, L.; Somsak, R.; Virapong, P. Bioactive metabolites from Spilanthes acmella Murr. Molecules 2009, 14, 850-867.

22. Ding, H.W.; Li, F.F.; Song, S.J. Chemical constituents from Portulaca oleracea L. J. Shenyang Pharm. Univ. 2009, 26, 878-881.

23. Tsai, P.W.; Kathlia, A.; Castro-Cruz, D.; Shen, C.C.; Chiou, C.T.; Ragasa, C.Y. Chemical constituents of Artocarpus camansi. Pharmacogn. J. 2013, 5, 80-82. 
24. Rabia, R.; Zaitoon, I.; Sajid, A.; Muhammad, N.; Muhammad, Y.K.; Jamshed, I. Identification of highly potent and selective $\alpha$-Glucosidase inhibitors with antiglycation potential, isolated from Rhododendron arboretum. R. Nat. Prod. 2015, 9, 262-266.

25. Li, N.; Di, L.; Gao, W.C.; Wang, K.J.; Zu, L.B. Cytotoxic iridoids from the roots of Patrinia scabra. J. Nat. Prod. 2012, 75, 1723-1728.

26. Di, L.; Li, N.; Zu, L.B.; Wang, K.J.; Zhao, Y.X.; Wang, Z. Three new iridoid glucosides from the roots of Patrinia scabra. Bull. Korean Chem. Soc. 2011, 32, 3251-3254.

27. Lin, S.M.; Molan, P.C.; Cursons, R.T. The in vitro susceptibility of Campylobacter spp. to the antibacterial effect of manuka honey. Eur. J. Clin. Microbiol. 2009, 28, 339-344.

28. Lin, S.M.; Molan, P.C.; Cursons, R.T. The controlled in vitro susceptibility of gastrointestinal pathogens to the antibacterial effect of manuka honey. Eur. J. Clin. Microbiol. 2011, 30, 569-574.

Sample Availability: Samples of the compounds of Portulacerebroside B-D and Portulaceramide A are available from the authors.

(C) 2015 by the authors; licensee MDPI, Basel, Switzerland. This article is an open access article distributed under the terms and conditions of the Creative Commons Attribution license (http://creativecommons.org/licenses/by/4.0/). 